10 Enhorning E. Hyaline membrane disease and artificial surfactant. In: Chiswick ML, ed. Recent advances in perinatal medicine. Edinburgh: Churchill Livingstone, 1983:191.

$"$ James DK, Tindall VR, Richardson T. Is the lecithin/spingomyelin ratio outdated? Br F Obstet Gynaecol 1983;90:995-1000.

12 Avery ME, Gatewood OB, Brumley G. Transient tachypnea of the newborn. Possible delayed resorption of fluid at birth. Am $\mathcal{F}$ Dis Child 1966; 111:380-5.

13 Mead P. Premature rupture of the membranes. In: Chiswick ML, ed Recent advances in perinatal medicine. Edinburgh: Churchill Livingstone 1983:77.

14 Halliday HL, McClure G, Reid MMcC. Transient tachypnoea of the newborn: two distinct clinical entities? Arch Dis Child 1981;56:322-5.

15 Xanthou M. Leucocyte blood picture in healthy full-term and premature babies during neonatal period. Arch Dis Child 1970;45:242-9.

${ }^{16}$ Folch J, Lees M, Sloane-Stanley GH. A simple method for isolation and purification of total lipids from animal tissues. F Biol Chem 1957;226: 497-509.

17 James DK, Harkes A, Williams M, et al. Amniotic fluid phosphatidylglycerol and prediction of fetal lung maturity in diabetic pregnancies. Fournal of Obstetrics and Gynaecology 1984;4:166-9.

18 James DK, Chiswick ML, Harkes A, Williams M, Tindall VR. Maternal diabetes and neonatal respiratory distress. 1. Maturation of fetal surfactant. Br $\mathcal{f}$ Obstet Gynaecol (in press).
${ }^{19}$ Hallman M, Kulovich MV, Kirkpatrick E, Sugarman RG, Gluck L. Phosphatidylinositol (PI) and phosphatidylglycerol (PG) in amniotic fluid; indices of lung maturity. Am f Obstet Gynecol 1976;125:613-7.

20 Obladen M, Merritt TA, Gluck L. Acceleration of pulmonary surfactant maturation in stressed pregnancies. Am $\mathcal{F}$ (Obstet Gynecol 1979;135: 1079-85.

21 Gluck L. Fetal lung development. Mead Fohnson Symp Perinat Dev Med 1980;14:40-9.

${ }^{22}$ Shelley SA, Kovacevic M, Piciga JE, Balis JU. Sequential changes of surfactant phosphatidylcholine in hyaline membrane disease of the newborn. N Engl f Med 1979;300:112-6.

${ }^{23}$ King RJ. Pulmonary surface-active material; basic concepts. Mead fohnson Symp Perinat Dev Med 1980;14:3-11.

24 Strang LB. Heterogeneity of pathogenic mechanisms in hyaline membrane disease. Mead Fohnson Symp Perinat Dev Med 1980;14:52-8.

${ }^{25}$ Staub NC. Effects of alveolar surface tension on the pulmonary vascular bed. Fpn Heart 7 1966;7:386.

${ }^{26}$ James DK, Harkes A. Dry artificial lung surfactant in prematurity. Lancet $1981 ; \mathrm{i}: 555$.

27 James DK, Chiswick ML, Harkes A, Williams N, Tindall VR. Maternal diabetes and neonatal respiratory distress. II. Prediction of fetal lung maturity. Br $\mathrm{F}$ Obstet Gynaecol (in press).

(Accepted 1 March 1984)

\title{
Neuropathy and fatal hepatitis in a patient receiving amiodarone
}

\author{
P K LIM, P N TREWBY, G C A STOREY, D W HOLT
}

\begin{abstract}
Muscle weakness, neuropathy, and transient rises in hepatic enzyme activity have been reported with the use of the antiarrhythmic agent amiodarone. A 68 year old teetotaller with normal liver function was given amiodarone for resistant supraventricular arrhythmias. He presented 19 months later with vomiting, muscle weakness and wasting, sensory neuropathy, and hepatomegaly. Liver biopsy showed fibrosis and the presence of hyaline. The amiodarone was withdrawn. Three months later he developed ascites. Oesophageal varices were found and he later died. The liver showed micronodular cirrhosis.

The large volume of distribution and long half life of amiodarone may explain the persistence of toxicity, which may have been aggravated by simultaneously administered doxepin in this case. Amiodarone should be withdrawn if abnormal liver function or neuropathy develops.
\end{abstract}

\section{Introduction}

Transient rises in hepatic enzyme activity have been reported in $40 \%$ of patients receiving the antiarrhythmic agent amiodarone. ${ }^{1}$ More severe liver damage has been mentioned but no details given. ${ }^{2}$ Muscle weakness and neuropathy have also been

Darlington Memorial Hospital, Darlington DL3 6HX

P K LIM, MB, senior house officer

P N TREWBY, MD, MRCP, consultant physician

Poisons Unit, Guy's Hospital, London SE1 9RT

G C A STOREY, BSC, biochemist

D W HOLT, BSC, PHD, principal biochemist

Correspondence to: Dr P N Trewby. described. ${ }^{3}$ We describe a patient with irreversible neuropathy and severe hepatitis progressing to cirrhosis, which was apparently caused by amiodarone.

\section{Case report}

In February 1981 the patient, aged 68, was given amiodarone, $400 \mathrm{mg}$ daily, for resistant supraventricular arrhythmias attributed to underlying ischaemic heart disease. Liver function was normal. The dose was increased to $600 \mathrm{mg}$ daily in June to control the arrhythmia. In October 1982 the patient presented with vomiting and muscle weakness of one month's duration. Examination showed striking muscle wasting and distal sensory polyneuropathy. The liver was enlarged and finger clubbing was present.

Other medication comprised digoxin (started November 1976), doxepin (August 1980), and bumetanide (June 1981). The patient was a lifelong teetotaller.

Results of investigations were: serum bilirubin concentration 28 $\mu \mathrm{mol} / 1(163.7 \mathrm{mg} / 100 \mathrm{ml})$; alkaline phosphatase activity $854 \mathrm{IU} / 1$; serum aspartate aminotransferase activity $142 \mathrm{IU} / 1$; serum albumin concentration $29 \mathrm{~g} / \mathrm{l}$; and negative results to tests for hepatitis B surface antigen, hepatitis A antibody, Venereal Disease Research Laboratory test, and autoantibodies; urinary porphyrins were not detected. Plasma concentrations of amiodarone and desethyl amiodarone were 5.0 and $4.0 \mathrm{mg} / 1$ respectively.

Needle liver biopsy showed periportal and centrilobular fibrosis with a moderate infiltrate of lymphocytes and plasma cells. The liver cells were swollen and some contained hyaline material resembling Mallory's hyaline. Amiodarone was withdrawn and there was a prompt fall in liver enzyme activity and a temporary clinical improvement (figure). Other medication remained unchanged.

Three months later he developed ascites and a barium swallow examination showed oesophageal varices. The patient died from liver failure five months after stopping amiodarone.

A postmortem liver biopsy showed established micronodular cirrhosis. Electron microscopy showed scattered multilamellar bodies, some with a distinct membrane suggesting a lysosomal origin.

Nerve conduction studies and electromyography performed shortly after admission suggested sensorimotor polyneuropathy of axonal type. Histological findings from the right quadriceps were also consistent with patchy denervation. 


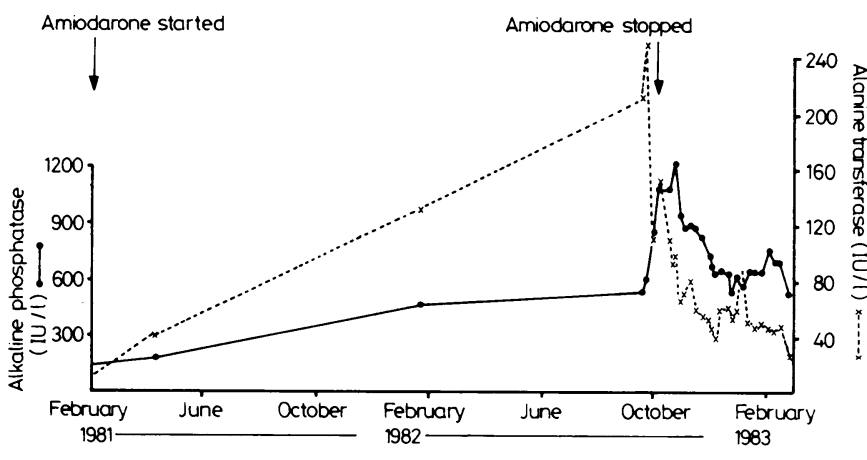

Serum enzyme concentrations in relation to amiodarone treatment.

Serial measurements of plasma amiodarone and desethyl amiodarone concentrations showed terminal elimination half lives of 51 and 53 days respectively. Postmortem amiodarone and desethyl amiodarone concentrations in liver were $170 \mathrm{mg} / \mathrm{kg}$ and $2960 \mathrm{mg} / \mathrm{kg}$ respectively, and the respective concentrations in muscle were 55 and $223 \mathrm{mg} / \mathrm{kg}$ one week after stopping amiodarone and 22 and 177 $\mathrm{mg} / \mathrm{kg}$ four months later.

\section{Discussion}

The fall in liver enzymes on stopping amiodarone suggests a causal relation between amiodarone ingestion and liver damage. The mechanism of toxicity is unknown but the accumulation of lamellated inclusion bodies suggests a drug induced disturbance of lipid metabolism and lysosomal function similar to that described in hepatitis and neuropathy related to perhexiline. ${ }^{3}$ Plasma concentrations of amiodarone and its main metabolite desethyl amiodarone were high on withdrawal of amiodarone, reflecting the large maintenance dose needed to control this patient's arrhythmia. The drug's large volume of distribution (in the order of 5000 litres) and long terminal elimination half life may explain the persistence of toxicity five months after withdrawal of amiodarone. The half life of amiodarone in our patient was similar to that reported in patients not developing liver disease 4 so a defect in amiodarone metabolism is unlikely to be the only cause of the toxicity.

Tricyclic antidepressants may also give rise to lamellated inclusion bodies in cultured cells, but not in human cells. ${ }^{5}$ The doxepin our patient was receiving could, however, have potentiated the adverse effects of amiodarone resulting in the rapid development of cirrhosis.

This case underlines the need to use the smallest effective dose of amiodarone in long term treatment. The drug and other potential hepatotoxins should be withdrawn if liver function test results become abnormal or neurological symptoms develop. Plasma measurements of amiodarone and desethyl amiodarone may be helpful.

We thank Drs P Hudgson, A R Morley, J Tregillus, and P J B Tilley for helpful advice, for the muscle and liver biopsy reports, and for carrying out the neurophysiological studies; and Miss Julie Elliott for typing the manuscript.

\section{References}

${ }^{1}$ McGovern B, Garan H, Kelly E, Ruskin JN. Adverse reactions during treatment with amiodarone hydrochloride. $B r$ Med $\mathcal{F} 1983 ; 287: 175-80$.

${ }^{2}$ Nademanee K, Singh BM. Adverse effects of amiodarone. $\mathcal{F} A M A 1982$; 248: 1448-9.

${ }^{3}$ Lemaire JF, Autret A, Biziere K, Romet-Lemone JL, Gray F. Amiodarone neuropathy: further arguments for human drug-induced neurolipidosis. Eur Neurol $1982 ; 21: 65-8$.

4 Holt DW, Tucker GT, Jackson P, Storey GCA. Amiodarone pharmacokinetics. Am Heart $\mathcal{F} 1983 ; \mathbf{1 0 6}: 840-7$.

${ }^{5}$ Lullmann-Rauch R. Drug-induced lysosomal storage disorders. Fron Biol $1979 ; 48: 49-130$.

(Accepted 29 March 1984)

\title{
Acute respiratory insufficiency after endoscopy for bleeding oesophageal varices
}

\author{
D C CRAWFORD, D W RYAN
}

\begin{abstract}
Two patients with alcoholic liver disease and gross ascites underwent endoscopic injection and compression by Sengstaken tube of oesophageal varices under general anaesthesia. Postoperatively both patients developed acute respiratory failure, which resolved after air had been aspirated from the stomach via the Sengstaken tube.

All air should be aspirated at the end of the procedure in patients with ascites who undergo endoscopy, and respiration should be carefully supervised postoperatively.
\end{abstract}

\footnotetext{
General Intensive Therapy Unit, Freeman Hospital, Newcastle upon Tyne NE7 7DN

D C CRAWFORD, MB, MRCP, registrar in anaesthetics

D W RYAN, MB, FFARCS, consultant clinical physiologist

Correspondence to: Dr D W Ryan.
}

\section{Introduction}

Diaphragmatic excursion is the principal muscular movement in achieving inspiration. ${ }^{1}$ In the presence of mechanical obstruction vital capacity and functional residual capacity fall appreciably. We report on two patients with alcoholic liver disease and gross ascites who developed acute respiratory failure after endoscopic injection of oesophageal varices under general anaesthesia.

\section{Case reports}

\section{CASE 1}

A 51 year old woman was admitted to this unit with bleeding oesophageal varices, gross ascites, and hepatic encephalopathy. Anaesthesia was induced with etomidate $12 \mathrm{mg}$ and suxamethonium $50 \mathrm{mg}$ and maintained with intermittent positive pressure ventilation together with $0.6 \%$ enflurane, oxygen, and $60 \%$ nitrous oxide. $\mathrm{Her}$ varices were injected with $5 \%$ ethanolamine oleate endoscopically and then compressed by a Sengstaken tube. 